\title{
Genetics of human asthma and equine recurrent airway obstruction: can these two diseases be compared?
}

\author{
Eliane Marti* and Lisa Harwood \\ Division of Clinical Immunology, Department of Clinical Veterinary Medicine, University of Berne
}

\begin{abstract}
Summary
Asthma in humans is a complex, atopic condition, influenced by environmental factors and a well-documented genetic component. Familial clustering has also been demonstrated for recurrent airway obstruction (RAO) in the horse, a disease which shares some similarities with human asthma. The human condition is well understood at the molecular level, with several of the genes involved characterised. However, very little is known about the potential genes involved in RAO. The human genome map has been completed and the positions of some of the genes involved in asthma have been localised to various chromosomes, and in particular to regions of chromosome 5. Comparison of this data with increasing knowledge of the horse genome map will produce candidate genes for RAO. The identification of genetic markers for RAO will enable the breeding of horses less susceptible to the disease, help in identifying animals at risk prior to the onset of symptoms and therefore allow the reduction of exposure to potentially disease-causing environmental factors. Finally, pharmacogenetics techniques in which the genetic basis which contributes to a disease status are analysed and used to identify new or optimise existing treatments could also be applied to RAO. This review highlights parallels between the two diseases and suggests potential areas of human knowledge which may be exploited to elucidate the genetic component of RAO.
\end{abstract}

Genetik des humanen Asthmas und der equinen Chronisch Obstruktiven Bronchitis: können beide Erkrankungen verglichen werden?

Keywords: Genetics, asthma, equine recurrent airway obstruction, RAO, heaves

\section{Genetik des Asthma beim Menschen und der Chronisch Obtruktiven Bronchitis des Pferdes - Sind beide Erkrankungen zu vergleichen?}

Das Asthma beim Menschen ist ein komplexer atopischer Zustand, der sowohl durch Umwelt- als auch durch genetische Faktoren beeinflusst wird. Auch für die Chronisch Obstruktive Bronchitis (COB, recurrent airway obstruction, RAO) des Pferdes wurde eine familiäre Häufung beschrieben. Diese Erkrankung scheint mit dem Asthma des Menschen gewisse Ähnlichkeiten aufzuweisen. Das Asthma ist auf der molekularen Ebene gut untersucht und ein Teil der beteiligten Gene wurde identifiziert. Über die Gene, die möglicherweise bei der COB des Pferdes involviert sind, ist andererseits fast nichts bekannt. Die Genomkarte des Menschen ist heute mehr oder weniger vollständig entschlüsselt und die Position einiger an Asthma beteiligten Gene konnte verschiedenen Chromosomen, insbesondere dem Chromosom 5 , zugeordnet werden. Durch Vergleiche der menschlichen Genomkarte mit der entstehenden Genomkarte des Pferdes wird es möglich werden, Kanidatengene für die COB zu finden. Die Identifizierung genetischer Marker für COB schafft einerseits die Möglichkeit, Pferde zu züchten, die für diese Erkrankung weniger anfällig sind, andererseits können risikobelastete Pferde frühzeitig erkannt werden, so dass sie von COB-begünstigenden Faktoren ferngehalten werden können. Erkentnisse der Pharmakogenetik können mithelfen, neue Behandlungsstrategien gegen $\mathrm{COB}$ zu entwickeln oder bestehende zu verbessern. Dieser Übersichtsartikel zeigt Parallelen zwischen dem Asthma beim Menschen und der COB beim Pferd auf und zeigt, dass Erkenntnisse aus der Humanmedizin dazu beitragen knnen, die Gene zu identifizieren, die für die erbliche Veranlagung für COB beim Pferd verantwortlich sind

Schlüsselwörter: Genetik, Asthma, COB, Chronisch Obstruktive Bronchitis, recurrent airway obstruction, RAO

\section{Human asthma}

Human asthma is a disease triggered by environmental factors which affects susceptible individuals and is characterised by airway hyperresponsiveness (AHR), eosinophilic inflammation and reversible airway narrowing. The major cause of human asthma is atopy, a condition characterized by a persistent and heritable lgE response to environmental allergens, such as pollens, mites and moulds. In man, the presence of a genetic predisposition for asthma and atopy has been shown many years ago (Cook and Van der Veer 1916) and more recently, twin and family studies have suggested a strong genetic link in asthma (Los et al., 2001; European
Community Respiratory Health Survey Group, 1997). This has also been demonstrated in genetic epidemiology experiments (Holgate et al., 1995). Asthma is a polygenic and multifactorial syndrome. It has genetic factors, which, coupled with environmental stimuli, interact in susceptible individuals to produce the phenotype. A model has been developed to describe the factors involved in potential disease development. An individual having several mutations in genes which may predispose them to developing asthma, only needs a small degree of environmental exposure in order to develop the disease, whereas an individual with fewer mutations needs greater exposure to environmental triggers to develop asthma. People with no mutations predisposing them to asth- 
ma would not develop the disease under any environmental conditions (Hall 2000).

Asthma is the result of complex immunological mechanisms and the genes regulating these pathological immune responses are most probably responsible for the genetic basis of asthma. Asthmatics have increased expression of the Th2 cytokines IL-4, IL-5, IL-9 and IL-13, which have been suggested to have a key role in atopic diseases (Wills-Karp et al 1998; Wills-Karp, 1999). Mouse and to a lesser extent human $\mathrm{T}$ helper (Th) lymphocytes can be divided into two major subsets on the basis of the types of the produced cyto-

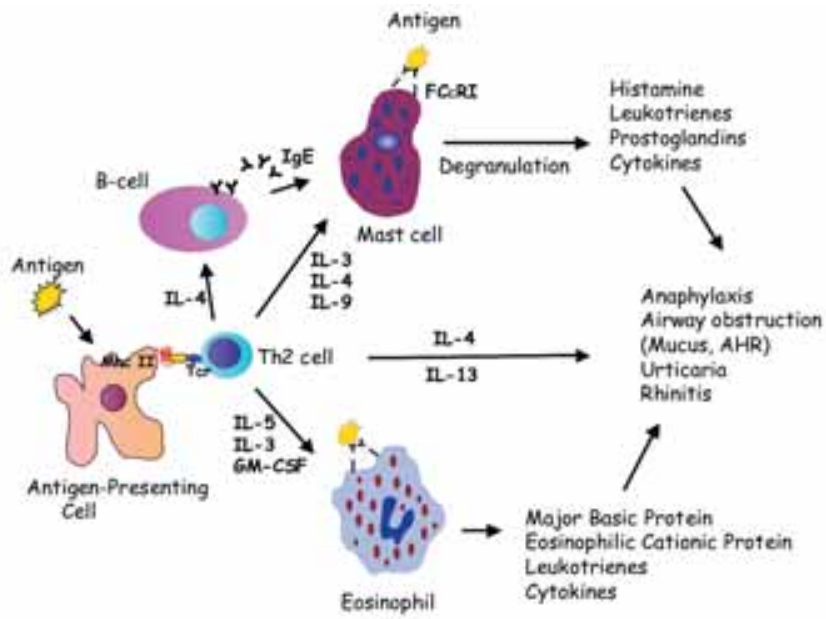

Fig 1 Environmental antigens encounter the immune system through the skin or mucosal surfaces and are taken up by an antigen-presenting cell. The antigen is then processed and presented, bound to Major histocompatibility class II (Mhc II) molecules, to the T-cell receptor (TCR) of a Th2 lymphocyte. Th2 cells produce the following cytokines: interleukin (IL)-4 required for B-cell maturation and immunoglobulin E (IgE) synthesis; IL-3, IL-5 and GM-CSF required for eosinophil growth and differentiation; IL-3, IL-4 and IL-9 for mast cell development. IgE produced by B-cells is bound at the cell surface by Fc e receptor I (FceRI) which is present on mast cells and eosinophils. Cross-linking of the receptor during subsequent encounters with antigen leads to degranulation of the mast cell and release of various mediators from mast cells and eosinophils, which elicit the clinical signs of atopic diseases. IL-4 and IL-13 can also participate in the pathogenesis of asthma through direct effects on lung tissue. Adapted from Foster et al. (2002).

kines, which are glycoproteins regulating the immune responses by signaling between cells. Th1 subsets produce mainly interleukin (IL)-2 and interferon (IFN)-g whereas the Th2 subset produces mainly IL-4, IL-5 and IL- 13 (Mosmann and Sad, 1996). To understand which genes could be of interest for the genetics of asthma an overview of the major immunological reactions leading to clinical signs of atopy or asthma is given in Figure 1.

Studying the genetics of asthma is also challenging because the asthma phenotype is complex and heterogeneous, therefore some characteristics of the diseases are not exhibited by some patients. This problem must be addressed when classifying phenotypes for genetic studies. Different asthmas are classed by precisely defined clinical and/or diagnostic criteria. Because of the complexity in developing a uniform definition of asthma, investigators have begun to study individual physiological characteristics that are closely associated with the development and progression of asthma, such as air- way hyperresponsiveness and elevated serum IgE levels, both components of the asthma phenotype that can be objectively measured. Different studies have shown that the ability to produce high or low lgE responses is inherited (Meyers 1993). Genetic factor also contribute to airway hyperresponsiveness $(A H R)$, one of the major features of asthma (Townley et al. 1986).

Identification of the genes involved in diseases can be studied in two ways, the first of which is the candidate gene approach in which the contribution of individual genes is investigated with regards to the development of the disease (disease-causing genes), its severity (disease-modifying genes) or the response to therapy (treatment-response genes) (Hall, 1998; Moffatt and Cookson, 1997; Cookson, 1999). This strategy is only applicable when genes can be rationally selected based on the pathogenesis of a disease or from comparative studies in other species. Secondly, linkage analysis studies examine whole or partial genomes for polymorphic genotypic markers which produce information on the loci and genes that are coinherited with disease markers and might contribute to the expression of the phenotype (Hopkin et al., 1991). Linkage analysis can only been performed when a genome map of the studied species is available. A genome map shows the chromosomal location of genes and markers and where they are located in relation to each other. Studies on diseases in mouse and man and on production traits in agricultural species have shown that detailed genetic maps are necessary to successfully investigate polygenic traits.

In humans, various genes or chromosomal regions associated with asthma or atopy have been identified through the candidate gene approach or through linkage analysis during the last 10 years. More than 10 genomic regions have been identified by linkage studies with connections to asthma (Wist and Immervoll 1998). In particular, chromosome 5q31-q33 contains the cytokine gene cluster which includes IL-3, IL-4, IL-5, IL-9 and IL-13 (Rosenwasser et al. 1995; Collins et al. 2000) as well as growth factors and receptors implicated in allergic inflammation (Postma et al., 1995). In mice with airway hyperresponsiveness (AHR), genes on chromosome 13 where the IL-9 gene is located (Nicolaides et al., 1997) have been implicated. This region is homologous to chromosome 5q31-q33 in humans. Various studies also indicate that one or several gene(s) on human chromosome 5q31-q33 exert(s) a general control on lgE production (Noguchi et al. 1998). Numerous investigations have provided evidence that, in addition to genetic factors which influence a general predisposition for high lgE levels, major histocompatibility complex class II genes (MHC II) are involved in the specific immune responsiveness to allergens (Barnes and Marsh 1998). The MHC gene region is also associated with asthma (Collins ef al. 2000). Furthermore, significant linkage of allergen-specific $\lg \mathrm{E}$ responses to the $\mathrm{TCRa} / \mathrm{b}$ region has been observed (Cookson 1998). Despite conflicting results, the involvement of other genes such as the FCeRI (Cookson 1998) and the IL4R (Hershey et al. 1997) have also been proposed.

\section{Equine recurrent airway obstruction}

Equine recurrent airway obstruction (RAO) or heaves, which is sometimes also known as chronic obstructive pulmonary dise- 
ase (COPD) or chronic bronchitis/bronchiolitis (CB), shares many characteristic features with asthma (Robinson 2001). However, in contrast to most asthmatic patients, horses have increased numbers of neutrophils rather than eosinophils in their airways. Equine RAO is a hypersensitivity reaction to mould spores present in hay and straw dust and/or to other allergens (Robinson et al. 1996). As this disease shares a number of similarities with the allergic bronchitis-asthma syndrome in man, it was suggested that expression of RAO was not only influenced by environmental factors (mouldy hay) but also by a genetic predisposition. The presence of a genetic predisposition for heaves was first suggested by several authors around the middle of the 20th century: Schaeper (1939) showed that 14 of 27 offspring from the heavey stallion 'Egmont' were also suffering from heaves. His study however, did not include a control group, i.e. offspring from a stallion that was not affected with RAO. Similar multiplecase families were also reported by other authors (Koch

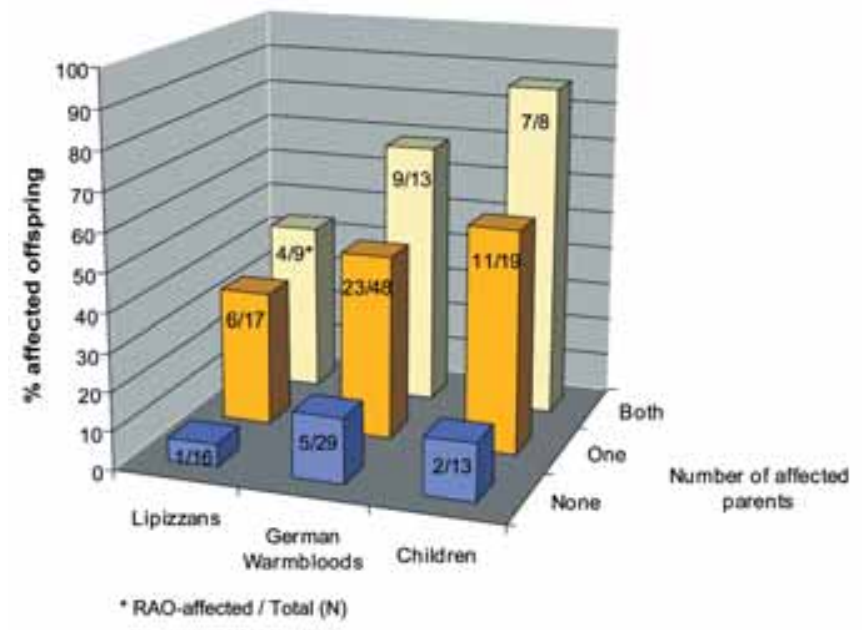

Fig 2 Clinical manifestation of recurrent airway obstruction in Lipizzan $(N=42)$ and German Warmblood $(N=90)$ horses or atopy in humans, depending on the clinical history of their parents (none, one or both affected).

1957, Gerber 1989). A more extensive study was performed in 1991 (Marti et al. 1991) to investigate whether a genetic predisposition for RAO could be demonstrated. This investigation was carried out in two different studs $(90$ German Warmblood and 42 Lipizzan horses, age $\Delta 8$ years, with known clinical history of their parents). Additionally, a third group was included in the study, consisting of 153 halfsiblings (age $\Delta 5$ years) from different farms and regions in Switzerland, sired by three healthy and three RAO-affected stallions. The 153 dams of this group could not be evaluated for a history of RAO. Figure 2 shows that in both studs the percentage of offspring suffering from RAO increases with increasing number of affected parents. In the German Warmblood stud, $17 \%, 48 \%$ and $69 \%$ of the offspring, respectively, were affected with RAO when none, one or both parents were affected with this disease $(p<0.005)$. Similar results were obtained in the Lipizzan stud (6\%, 35\% and $44 \%$, respectively, $p=0.062$ ). Interestingly, these findings were quite similar to the results from a study on the inheritance of atopy in humans (Fig 1, Cookson and Hopkin 1988). In both horse groups, the sex of the affected parent did not influence the susceptibility to RAO in the offspring. There were fewer RAO-affected offspring in the Lipizzan stud than in the German Warmblood stud.
However, this difference between the two studs, which might be due to environmental or genetic factors, was statistically not significant.

The overall results from the 153 Swiss halfsiblings showed that stallions with RAO sired significantly more affected offspring (31 out of 79) than healthy stallions (9 affected offspring out of 74). Additionally, the 153 Swiss halfsiblings were grouped according to their age (four age groups: 5-7, 8-10, $11-13, \Delta 14$ years) and according to the clinical status of their sires (Fig 2). In each halfsibling group the frequency of affected horses increased with increasing age. However, in each age group, the percentage of affected horses was higher in the group of offspring sired by RAO-affected stallions than in those produced by healthy sires. An analysis of variance showed that sire, age and environment (stable) all exerted a significant effect on the disorder.

This study also showed that offspring with one RAO-affected parent had a 3.2 higher risk $(p<0.05)$ to suffer from RAO than offspring from healthy parents. When both parents were affected, the risk that the offspring would suffer from RAO was 4.6 times greater than when both parents were healthy $(p<0.05)$.

This investigation demonstrates that genetic factors play an important role in the pathogenesis of RAO. Interestingly, these findings display striking similarities with some studies on the genetics of asthma in humans (Black and Marsh 1976): Affected individuals have a higher percentage of positive family histories, the predisposition and not the disease is transmitted, and the mode of inheritance is not clear. Although the genes influencing the genetic susceptibility for RAO have not been identified, we can speculate that, as is the case with human asthma, a number of different genes are

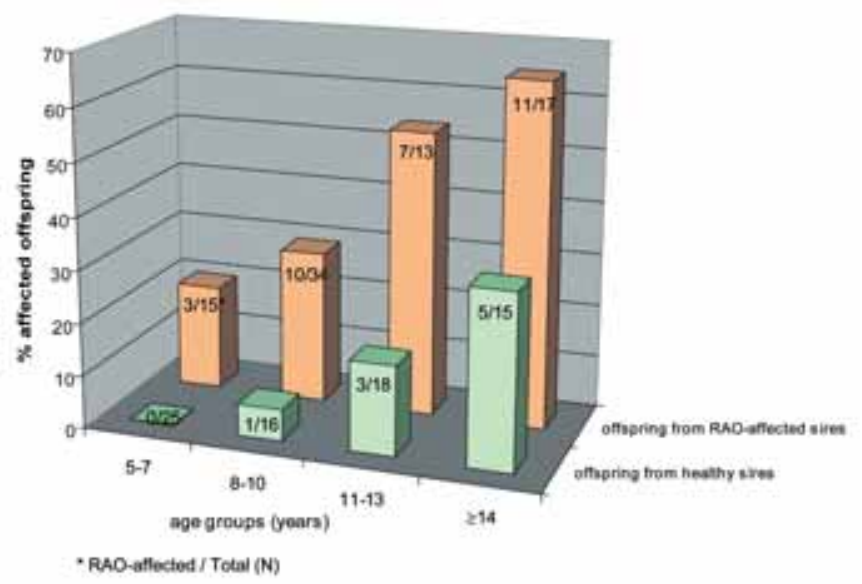

Fig 3 Clinical manifestation of recurrent airway obstruction (RAO) in offspring from three healthy and three RAO-affected sires.

involved.

Although the pathogenesis of RAO is still not fully understood, a number of studies suggest that immunoglobulin $E$ ( $\lg E$ ) against moulds or other allergens may be involved in the pathogenesis of this disease (Halliwell et al. 1993; Eder et al. 2000). In a recent study (Eder et al. 2001), IgE levels against moulds were determined in sera from 450 Lipizzan horses from six different studs. Analysis of the results showed that, as 
is the case in humans, not only the environment, but also genetic factors influence the specific lgE response. Heritability estimates of 0.33 were found for lgE levels against moulds. This means that $33 \%$ of the variation of the $\mathrm{IgE}$ levels were due to genetic factors. Further studies are now needed to elucidate if genes influencing the $\lg E$ response account for the genetic predisposition to RAO and to identify the genes responsible for the heritability of lgE levels. Genes within the MHC gene region have been demonstrated to influence the lgE response against some specific mould allergens (Curik et al. 2002). However, various other genes will probably also influence specific and total lgE levels in the horse.

The next goal will be to identify genetic markers or genes influencing the genetic predisposition for RAO. An interesting candidate gene region will certainly be equine chromosome 14, which corresponds to human chromosome 5, where the Th2 cytokine gene cluster is located, because Th2 responses appear to play a role in equine RAO: increased levels of both IL-4 (Lavoie et al. 2001; Giguere et al. 2002) and IL-13 (Bowles et al. 2002) have been detected in the airways of horses with RAO. However, some studies also detected a concomitant increased expression of IFNg (Giguere et al. 2002), suggesting that not only Th2 responses are involved in the pathogenesis of RAO.

A prerequisite for finding genetic markers is the availability of a genome map of the horse showing the chromosomal location of genes and markers. The horse genome map has been constructed through an international collaboration over the last seven years (http://locus.jouy.inra.fr;http://www. uky.edu/-ag/horsemap) and has now reached the stage where it can begin to be used for finding genetic markers for different traits in the horse.

Knowledge from other species can also help to identify the genes involved in RAO, as it is possible to compare other mammalian genome sequences with that of the human. This aids discovery and annotation of gene structures and other functionally important sequences in species where the genome is less well studied than in human. The availability of the human genome has already benefited researchers in the elucidation of the mouse genome (Gregory et al., 2002). Similarly, the on-going horse genome project will benefit from this knowledge. Because the majority of genes in mammals are conserved in large blocks, comparative mapping allows the transfer of information from human and mouse, where the genome has been extensively studied, to other species such as the horse, where there is relatively little information available. Once a gene is localised to a region of a horse chromosome, predictions can be made about neighbouring genes by comparison with genome information from other species. In essence, it is possible to use the human map/DNA sequence as a model for equine genetics. The corresponding human chromosomes for the majority of horse chromosomes have already been identified (Raudsepp et al. 1996).

The practical consequences of these studies will be the availability of genetic markers for RAO which could allow the breeding of animals less susceptible for this disease. However, we have to keep in mind that some of these susceptible horses may have other positive traits which breeders want to select for, and that the breeders/owners will always have to weigh the risk of having a horse predisposed to RAO against other valuable traits of this individual. Exclusion from breeding of individuals predisposed for RAO might be difficult because of the relatively high prevalence of this condition (Robinson et al. 1996). Genetic tests could also be used to identify animals with a high risk for allergic disease early in life and to prevent expression of the disease through control of the environment in which the horse lives, i.e. by reducing exposure to allergens as much as possible. Furthermore, in the future, knowing which genes contribute to the disease in each individual horse may allow to choose the most efficient treatment for this particular patient: Pharmacogenetics (Kalow 1965; Palmer et al. 2002) is a research area in which the genetic basis of a disease is used to improve current treatments and to develop new ones. The understanding of genetic factors which contribute to disease status is important when trying to identify new therapeutic targets and optimising currently available therapy for individual cases. Treatments or disease-control programmes which work well with one patient are not necessarily best for other phenotypes.

In conclusion, equine genetics as a whole will profit from the extensive information provided by the human genome project. Within the context of equine allergic diseases like RAO, the comparison with asthma could yield the genes responsible for this complex disease. However, for selecting the right candidate genes, further studies on the pathogenesis of RAO are necessary to see whether similar pathophysiological mechanisms are responsible for RAO and human asthma.

\section{Literature}

Barnes, K.C. and Marsh, D.G. (1998) The genetics and complexity of allergy and asthma. Immunology Today 19, 325-334

Black, P.L., and Marsh, D.G. (1976) The genetic basis for atopic allergy in man. In: Bronchial Athma, Mechanisms and Therapeutics. Ed. Weiss E.B. and Segal, M.S. Little Brown and Company Boston, pp 53-64

Bowles, K. S., R. E. Beadle, S. Mouch, S. S. Pourciau, M. A. LittlefieldChabaud, C. Le Blanc, L. Mistric, D. Fermaglich, and D. W. Horohov. (2002) A novel model for equine recurrent airway obstruction. Vet Immunol Immunopathol 87, 385-389

Collins, A., Ennis, S., Tapper, W. and Morton, N.E. (2000) Mapping oligogenes for atopy and asthma by meta-analysis. Genetics and Molecular Biology 23, 1-10

Cook R.A. and Van der Veer A. (1916) Human sensitisation. J. Immunol. 1, 201-305.

Cookson WO and Hopkin JM. (1988) Dominant inheritance of atopic immunoglobulin-E responsiveness. Lancet 1 (8577), 86-88

Cookson, W.O.C.M. (1998) Genetics and asthma. Res. Immunol. $149,181-187$

Cookson, W (1999) The alliance of genes and environment in asthma and allergy. Nature, 402, B5-B1 1

Curik, I., Fraser, D., Eder, C., Achmann, R., Swinburne, J., Binns, M., Crameri, R, Brem, G., Soelkner, J. and Marti, E. (2002) Association between the $M H C$ gene region and serum IgE levels against specific mould allergens in the horse. Genet Sel Evol. (submitted)

Eder, C., Crameri, R., Mayer, C., Eicher, R., Straub, R., Gerber, H. and Lazary, S. and Marti, E. (2000) Allergen-specific lgE levels against crude mould and storage mite extracts and recombinant mould allergens in sera from horses affected with chronic bronchitis. Vet. Immunol. Immunopathol. 73, 241-253 
Eder, C., Curik, I., Brem, G., Crameri, R., Bodo, I., Habe, F., Lazary, S., Sölkner, J., and Marti, E. (2001) Influence of environmental and genetic factors on allergen-specific immunoglobulin $E$ levels in sera from Lipizzan horses. Equine Vet. J. 33, 714-720

European Community Respiratory Health Survey (1997) Group genes for asthma? An analysis of the European Community Respiratory Health Survey. Am. J. Respir. Crit. Care Med. 156, 1773 1780.

Gerber H. (1989) The genetic basis of some equine diseases. Sir Frederick Hobday Lecture. Equine Vet. J. 21, 244-248

Giguere, S., L. Viel, E. Lee, R. J. MacKay, J. Hernandez, and M. Franchini. (2002) Cytokine induction in pulmonary airways of horses with heaves and effect of therapy with inhaled fluticasone propionate. Vet. Immunol. Immunopathol. 85, 147-158

Gregory, S.G., Sekhon, M., Schein, J., Zhao, S., Osoegawa, K., Scott, C.E., Evans, R.S., Burridge, P.W., Cox, T.V., Fox, C.A., Hutton, R.D., Mullenger, I.R., Phillips, K.J., Smith, J., Stalker, J., Threadgold, G.J., Birney, E., Wylie, K., Chinwalla, A., Wallis, J., Hillier, L., Carter, J., Gaige, T., Jaeger, S., Kremitzki, C., Layman, D., Maas, J., McGrane, R., Mead, K., Walker, R., Jones, S., Smith, M., Asano, J., Bosdet, I., Chan, S., Chittaranjan, S., Chiu, R., Fiell, C., Fuhrmann, D., Girn, F., Gray, C., Guin, R., Hsiao, L., Krzywinski, M., Kutsche, R., Lee, S.-S., Mathewson, C., McLeavy, C., Messervier, S., Ness, S., Pandoh, P., Prabhu, A.-L., Saeedi, P., Smailus, D., Spence, L., Stott, J., Taylor, S., Terpstra, W., Tsai, M., Vardy, J., Wye, N., Yang, G., Shatsman, S., Ayodeji, B., Geer, K., Tsegaye, G., Shvartsbeyn, A., Gebregeorgis, E., Krol, M., Russell, D., Overton, L., Malek, J.A., Holmes, M., Heaney, M., Shetty, J., Feldblyum, T., Nierman, W.C., Catanese, J.J., Hubbard, Tim., Waterston, R.H., Rogers, J., de Jong, P.J., Fraser, C.M., Marra, M., McPherson, J.D. and Bentley D.R.(2002) A physical map of the mouse genome. Nature 418, 743-750

Hall, I.P. (1998) The genetics of asthma. Candidate gene approaches: gene-environment interactions. Clin. Exp. Allergy 28, 74-76

Hall, I.P. (2000) Pharmacogenetics of asthma. Eur. Respir. J. 15, 449-451

Halliwell REW, McGorum BC, Irving P, et al.(1993): Local and systemic antibody production in horses affected with chronic pulmonary disease. Vet. Immunol. Immunopathol. 38, 201-215

Hershey, G.K., Friedrich, M.F., Esswein, L.A., Thomas, M.L., Chatila, T.A. (1997) The association of atopy with a gain-of-function mutation in the alpha subunit of the interleukin-4 receptor. N. Engl. J. Med. 337, 1720-1725

Holgate, S.T., Church, M.K., Howarth, P.H., Morton, E.N., Frew, A.J. and Diukanovic, R. (1995) Genetic and environmental influences on airway inflammation in asthma. Int. Arch. Allergy Immunol. 107, 29-33

Hopkin, J.M., Cookson, W.O. and Young, R.P. (1991) Asthma, atopy and genetic linkage. Ann. NY Acad. Sci. 629, 26-30

Kalow, W. (1965) Contribution of hereditary factors to the response to drugs. Fed. Proc. 24, 1259-1262

Koch P. (1957) Heredity of chronic alveolar emphysema of the lungs in horses. Deutsche Tieraerztliche Wochenschrift 64, 485-486

Lavoie JP, Maghni K, Desnoyers M, Taha R, Martin JG, Hamid QA. (2001) Neutrophilic airway inflammation in horses with heaves is characterized by a Th2-type cytokine profile. Am. J. Respir. Crit. Care Med. 164, 1410-1413

Los, H., Postmus, P.E. and Boomsma, D.I. (2001) Asthma genetics and intermediate phenotypes: a review from twin studies. Twin Res. 4, 81-93

Marti, E., Gerber, H., Essich, G., Ouhlela, J. and Lazary, S. (1991) On the genetic basis of equine allergic diseases. I. Chronic hypersensitivity bronchitis. Equine Vet. J. 23, 457 - 460
Meyers, D.A. (1993) Genetics of atopic allergy: family studies of total serum IgE levels. in: The Genetics of Asthma. Eds Marsh D.G., Lockhart A. and Holgate S.T. Blackwell Scientific Publications, Oxford, UK. pp. 153-161

Moffatt, M.F. and Cookson, W.O. (1997) Linkage and candidate gene studies in asthma. Am. J. Respir. Crit. Care Med. 156, $110-$ 112

Mosmann, T.R. and Sad, S. (1996) The expanding universe of T-cell subsets: Th1, Th2 and more. Immunol. Today 17, 138-146

Nicolaides, N.C., Holroyd, K.J., Ewart, S.L., Eleff, S.M., Kiser, M.B., Dragwa, C.R., Sullivan, C.D., Grasso, L., Zhang, L.Y., Messler, C.J., Zhou, T., Kleeberger, S.R., Buetow, K.H. and Levitt, R.C. (1997) Interleukin-9 and its receptor in allergic and nonallergic lung disease: increased expression in asthma. Proc. Natl. Acad. Sci. USA 94, 13175-13180

Noguchi, E., Shibaski, M., Arinami, T., Takeda, K., Yokouchi, Y., Kawahima, T., Yanagi, H., Matsui, A. And Hamaguchi, H. (1998) Association of asthma and the interleukin-4 promoter gene in Japanese. Clin. Exp. Allergy.28, 449-453

Palmer, L.J., Silverman, E.S., Weiss, S.T. and Drazen, J.F. (2002) Pharmacogenetics of asthma. Am. J. Crit. Care Med. 165, 861-866

Postma, D.S., Bleecker, E.R. Amelung, P.J., Holroyd, K.J., Xu, J., Panhuysen, C.L., Meyers, D.A. and Levitt, R.C. (1995) Genetic susceptibility to asthma-bronchial hyperresponsiveness coinherited with a major gene for atopy. N. Engl. J. Med. 333, 894-900

Raudsepp, Fronicke, L., Scherthan, H., Gustavsson, I. And Chowdhary, B.P. (1996) Zoo-FISH delineates conserved chromosomal segments in horse and man. Chromosome Res. 4, 1-8

Robinson, N.E., Derksen, F.J., Olszeweski, M.A., Buechner-Maxwell, V.A. (1996) The pathogenesis of chronic obstructive pulmonary disease of horses. Br. Vet. J. 152, 283-306

Robinson, N.E. (2001) International Workshop on Equine Chronic Airway Disease, Michigan State University, 16-18 June 2000. Equine Vet. J. 33, 5-19

Rosenwasser, L.J., Klemm, D.J., Dresback, J.K., Inamura, H., Mascali, J.J., Klinnert, M. and Borish, L. (1995) Promoter polymorphism in the chromosome 5 gene cluster in asthma and atopy. Clin. Exp. Allergy. 25, 74-78

Schaeper W. (1939) Untersuchungen veber die Erblichkeit und das Wesen des Lungendampfes beim Pferd. Tieraerztliche Rundschau 31, 595-599

Townley RG, Bewtra A, Wilson AF, Hopp RJ, Elston RC, Nair N, Watt $G D$. (1986) Segregation analysis of bronchial response to methacholine inhalation challenge in families with and without asthma. J Allergy Clin. Immunol. 77, 101-107

Wills-Karp, M., Luyimbazi, J., Xu, X., Schofield, B., Neben, T.Y., Karp, C.L. and Donaldson, D.D. (1998) Interleukin-13: Central mediator of allergic asthma. Science, 282, 2258-2261

Wills-Karp, M. (1999) Immunologic basis of antigen-induced airway hyperresponsiveness. Annu. Rev. Immunol. 17, 255-281

Wist, M. and Immervoll, T. (1998) An internet linkage and mutation database for the complex phenotype asthma. Bioinformatics 14, 827-828

Dr. Eliane Marti

Division of Clinical Immunology

Department of Clinical Veterinary Medicine

Länggass-Strasse 124

CH- 3012 Berne

eliane.marti@itz.unibe.ch 